\title{
KEPADATAN DAN STRUKTUR POPULASI MONYET EKOR PANJANG (Macaca fascicularis) DI KAWASAN HUTAN KOTA TELUK AKAR BERGANTUNG KETAPANG KALIMANTAN BARAT
}

(Density and Structure of The Population of Long-tailed Macaque (Macaca fascicularis) in The Area of Teluk Akar Bergantung City Forest on Ketapang, West Kalimantan)

\author{
Farida Nurul Jannah, Erianto, Iswan Dewantara \\ Fakultas Kehutanan Universitas Tanjungpura Jalan Daya Nasional Pontianak 78124 \\ Email : faridanuru1512@gmail.com
}

\begin{abstract}
Long-tailed macaque (Macaca fascicularis) are one of the primates that are quite widespread in Indonesia, one of its in the area of Teluk Akar Bergantung city forest on Ketapang, West Kalimantan. This study aims to obtain data on the number of groups, number of individuals, population density, and structure of long-tailed macaque populations in the region using the line transects method and concentration count method. At the $95 \%$ confidence interval, the number of individuals ranged from -1,38 ind/ha to 30,20 ind/ha and the number of groups ranged from 0,72 groups/ha to 2,70 groups/ha. Population individual densities ranged from -0,39 ind/ha to 8,83 ind/ha and population group densities ranged from 0,21 groups/ha to 0,79 groups/ha. Structure of long-tailed macaque in the area of Teluk Akar Bergantung city forest on Ketapang, consists of 7,67 individuals of adult male, 9 individuals of adult female, 23,67 individuals of adolescent and 1,33 individual of children. Factors that affect the stability of long-tailed macaque populations include environmental conditions, types of feed, movement, interaction with other animals and the presence of predators.
\end{abstract}

Keywords: Long-tailed macaque, population density, population structure, Teluk Akar Bergantung city forest.

\section{PENDAHULUAN}

Monyet ekor panjang (Macaca fascicularis) merupakan salah satu spesies satwa primata yang hidup di Indonesia (Iskandar dan Kyes, 2016), yang tersebar cukup luas di Indonesia diantaranya Sumatera, Kalimantan, Jawa, Kepulauan Sunda kecil, dan Papua (Perwitasari dan Farajallah, 2016). Salah-satunya ditemukan di Hutan Kota Teluk Akar Bergantung. Kawasan ini terletak dan ditetapkan di Kabupaten Ketapang didasarkan pada Surat Keputusan Bupati Ketapang Nomor 150 Tahun 2004 tanggal 27 Mei 2004 dan mengacu pada Peraturan Pemerintah
Republik Indonesia Nomor 63 Tahun 2002 tentang Hutan Kota.

Menurut IUCN dan CITES monyet ini belum masuk kategori satwa dilindungi, menyebabkan monyet ekor panjang rentan terhadap perburuan, namun pemanfaatannya sudah diatur dalam Keputusan Menteri Kehutanan Nomor: 26/Kpts-II/94 tanggal 20 Januari 1994 tentang Pemanfaatan jenis Monyet Ekor Panjang (Macaca fascicularis), Beruk (Macaca nemestrina), dan Ikan Arwana (Scleropagus formosus) untuk keperluan ekspor. Peraturan tersebut menerangkan bahwa pemanfaatan monyet ekor panjang untuk keperluan 
ekspor tidak boleh dengan pengambilan langsung di alam dan harus berasal dari hasil penangkaran.

Pada suatu populasi dikenal istilah densitas (kepadatan) yang menjadi tolak ukur jumlah populasi dalam suatu kawasan. Sebagai salah satu sifat populasi, densitas merupakan cerminan ukuran populasi (jumlah total individu) yang hidup dalam kawasan tertentu (Tobing, 2008).

Tingginya kepadatan populasi pada suatu habitat akan mengakibatkan tingginya frekuensi ketegangan, perkelahian, dan agresifitas antar anggota sekelompok atau antar kelompok. Beberapa anggota populasi akan keluar dari habitatnya untuk menghindari ketegangan atau perkelahian.

Struktur yang terdiri dari kelas umur dan sex rasio sangat berpengaruh terhadap suatu kelompok populasi monyet ekor panjang. Menurut Subiarsyah et. al. (2014), untuk mengetahui jumlah populasi, sensus dilakukan dengan menghitung seluruh jumlah monyet pada masing-masing kelompok sosial, dan untuk mengetahui demografi, penghitungan dilakukan dengan membedakan jenis kelamin yaitu jantan dewasa, betina dewasa dan umur yaitu muda dan anakan pada masingmasing kelompok sosial.

Hutan Kota Teluk Akar Bergantung merupakan kawasan hutan rawa air tawar yang memiliki keanekaragaman jenis yang cukup tinggi salah-satunya yaitu monyet ekor panjang. Monyet ekor panjang memiliki manfaat yang cukup besar, tapi juga dapat menjadi ancaman bagi manusia. Satwa ini disebut sebagai edge species karena suka berada di wilayah pinggiran hutan, akibatnya di berbagai wilayah keberadaannya sering tumpang tindih dengan keberadaan manusia (Gumert et. al., 2012). Posisi Hutan Kota Teluk Akar Bergantung yang dikelilingi sungai dan pemukiman penduduk menyebabkan monyet ekor panjang tidak dapat menambah home range apabila terjadi peningkatan populasi, sehingga populasi monyet ekor panjang di kawasan ini memiliki kemungkinan mengalami kelebihan daya dukung (carrying capacity) yang berpotensi menjadikannya tumpang tindih lahan dengan pemukiman manusia. Oleh karena itu populasi monyet ekor panjang di kawasan ini harus dikendalikan.

Hasil yang diperoleh dapat dijadikan sebagai bahan pertimbangan terkait daya dukung Hutan Kota Teluk Akar Bergantung terhadap populasi monyet ekor panjang yang hidup di dalamnya. Berdasarkan hal tersebut peneliti tertarik untuk melakukan pengamatan tentang kepadatan populasi monyet ekor panjang ini.

\section{METODE PENELITIAN}

Penelitian dilaksanakan selama 12 hari mulai tanggal 16-27 Agustus 2018 dan dilakukan di kawasan Hutan Kota Teluk Akar Bergantung Desa Sukaharja, Kecamatan Delta Pawan, Ketapang, Kalimantan Barat dengan luasan 91 hektar. Alat yang digunakan dalam penelitian ini antara lain peta, GPS, binokuler, kamera, kompas, tally sheet, 
jam tangan, alat tulis, meteran, tali, dan counter. Objek yang diamati adalah monyet ekor panjang. Prosedur dalam penelitian ini antara lain penentuan lokasi pengamatan, pengambilan data primer dan sekunder, pengolahan dan analisis data. Metode yang digunakan dalam penelitian yaitu metode survei dengan teknik pengambilan data menggunakan metode jalur (line transects method) dan metode terkonsentrasi (concentration count), sedangkan untuk memperoleh data struktur populasi, monyet ekor panjang dibagi ke dalam 3 kelas umur yaitu kelas umur dewasa (jantan dan betina), remaja dan anak. Kelas umur setiap individu di alam tidak dapat ditentukan secara pasti atau kuantitatif, sehingga pengelompokkan umur setiap individu dilakukan berdasarkan besaran kualitatif atau penentuan kelas umur dilakukan berdasarkan pengamatan pada morfologinya. Secara morfologi dapat ditentukan kelas umur berdasarkan ciriciri fisik, ukuran tubuh, dan tingkah laku.

Menurut Soma et. al., (2009), monyet jantan dewasa ditandai oleh adanya scrotum, bantalan duduk menyatu dan tingkah lakunya relatif superior. Monyet betina ditandai oleh bantalan duduk kiri dan kanan terpisah, adanya vulva vagina, ambing dan puting susunya sudah menggelantung (pendulus). Pada kelompok muda, monyet jantan badannya lebih kecil dan tingkah lakunya permisif terhadap jantan dewasa, dan betina muda yang belum menunjukkan puting susu yang menggelantung. Monyet yang baru lahir dan monyet yang masih memiliki warna hitam pada rambut kepala dikelompokkan sebagai anakan.

Peletakan jalur dilakukan dengan mempertimbangkan keterwakilan luas kawasan. Berdasarkan pertimbangan tersebut maka didekati dengan metode inventarisasi menggunakan komponen base line. Jalur dibuat sebanyak 3 jalur dengan panjang masing-masing jalur yaitu $801 \mathrm{~m}, 846 \mathrm{~m}$, dan $405 \mathrm{~m}$. Lebar masing-masing jalur sama yaitu $25 \mathrm{~m}$ disisi kiri dan $25 \mathrm{~m}$ disisi kanan. Jarak antar jalur adalah $555 \mathrm{~m}$.

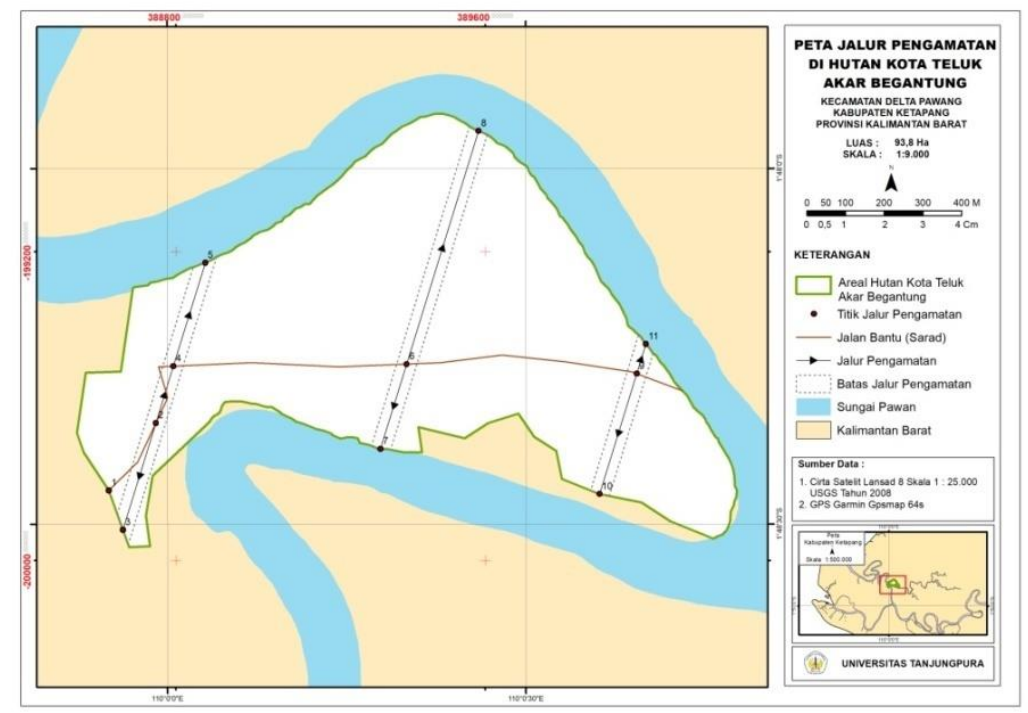


Data yang dikumpulkan berupa data populasi yang mencakup jumlah individu, jumlah kelompok dan struktur umur (jantan dewasa, betina dewasa, remaja dan anak). Pengamatan dilakukan pada pagi hingga sore hari pada pukul 08.00-17.00 WIB. Pengamatan dilakukan sebanyak 3 kali ulangan pada masing-masing jalur.

Data yang dikumpulkan dimasukkan kedalam tabel kemudian dihitung jumlah individu dan jumlah kelompok populasi serta pendugaan selang kepadatan individu/ha dan kepadatan kelompok/ha menggunakan rumus statistik pendugaan selang kepadatan populasi.

\section{HASIL DAN PEMBAHASAN}

Berdasarkan penelitian yang telah dilakukan, diketahui bahwa pada Kawasan Hutan Kota Teluk Akar Bergantung terdapat beberapa kelompok monyet ekor panjang yang tersebar dibeberapa titik. Monyet ekor panjang di kawasan ini sangat terbiasa dengan kehadiran manusia, bahkan sebagian besar sangat bergantung terhadap manusia dalam hal memperoleh makanan. Kelompok yang ditemukan selama penelitian sebanyak 4 kelompok dengan jumlah individu sebanyak 42 ekor dan pada satiap kelompok berkisar antara 11-14 ekor.

Kepadatan Individu dan Kelompok Populasi Monyet Ekor Panjang (Macaca fascicularis)

Kepadatan individu dan kelompok di seluruh areal Hutan Kota Teluk Akar Bergantung dengan selang kepercayaan 95\% masing-masing yaitu kepadatan individu terletak antara $-0,39-8,83$ individu/ha dan kepadatan kelompok/ha terletak antara 0,21 - 0,79 kelompok/ha. Kepadatan untuk setiap jalur dapat dilihat pada Gambar 1.

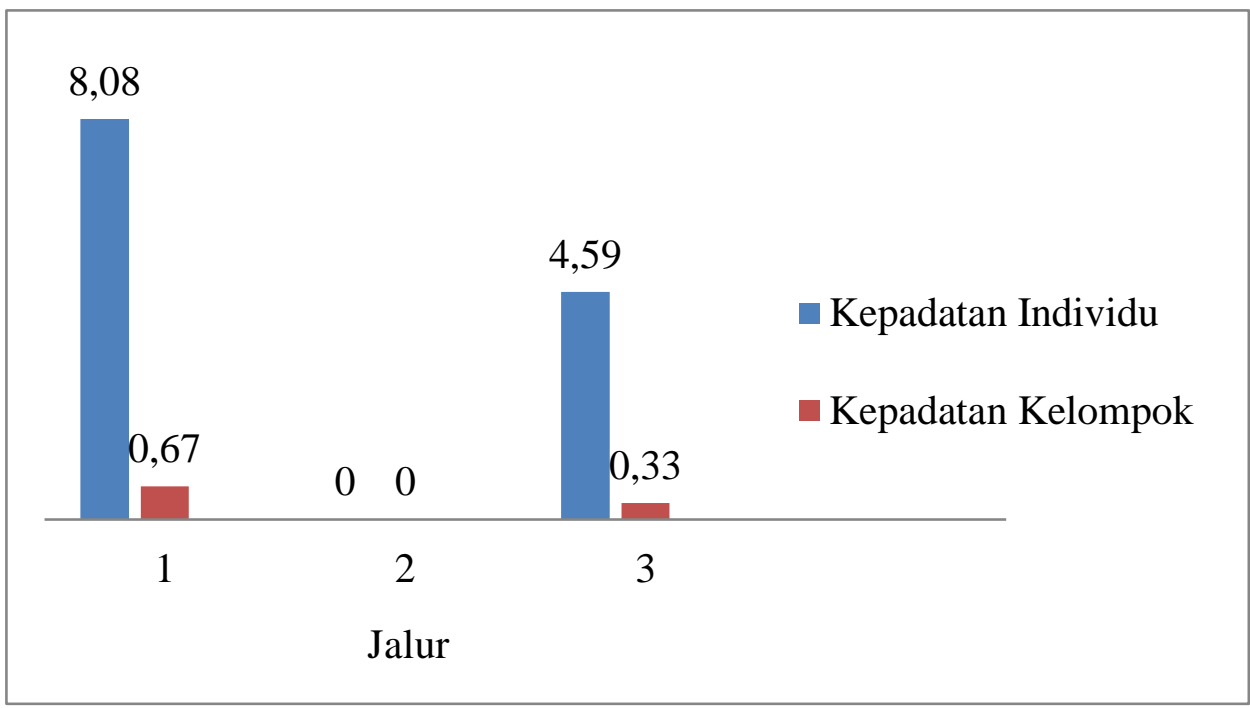

Gambar 1. Kepadatan individu dan kelompok monyet ekor panjang di masingmasing jalur pengamatan (density of individuals and groups of longtailed macaque in each observation pathway) 
Berdasarkan Gambar 1, terlihat bahwa kepadatan individu terbesar terdapat pada jalur 1 yaitu sebanyak 8,08 ind/ha dan kepadatan individu terkecil terdapat pada jalur 2 yaitu 0 ind/ha atau tidak terdapat sama sekali. Pada jalur 2 tidak ditemukan individu dan kelompok populasi. Begitu pula dengan kepadatan kelompok, kepadatan kelompok terbesar terdapat pada jalur 1 yaitu sebesar 0,67 $\mathrm{kel} / \mathrm{ha}$ dan kepadatan kelompok terkecil terdapat pada jalur 2 yaitu sebesar 0 $\mathrm{kel} / \mathrm{ha}$ atau tidak ditemukan individu dan kelompok populasi. Ini menunjukkan bahwa persebaran populasi pada lokasi penelitian tidak merata. Pada jalur 3 hanya ditemukan 1 kelompok populasi monyet ekor panjang pada ulangan 2 dan 3. Diduga pada ulangan pertama kelompok ini belum memasuki jalur penelitian. Pada jalur ini, monyet ekor panjang hanya memakan pakan alam seperti dedaunan dari beberapa pohon yang tidak berbuah. Kelompok yang memisahkan diri ini tidak menunjukkan sifat agresif sebagaimana seharusnya sifat kelompok yang jarang berinteraksi dengan manusia. Diduga kelompok ini juga tidak menetap lama pada area tersebut, dan seringkali berpindah tempat dengan jarak yang jauh meninggalkan kelompok lainnya. Kepadatan individu pada jalur 3 yaitu sebesar 4,59 ind/ha, sedangkan kepadatan kelompoknya adalah 0,33 $\mathrm{kel} / \mathrm{ha}$.

Terdapat beberapa faktor yang mempengaruhi persebaran monyet ekor panjang di lokasi penelitian, diantaranya sumber pakan dan kondisi vegetasi. Pada jalur 1 ditemukan banyak sumber pakan dan vegetasi. Menurut penjaga hutan kota, selain pakan langsung yang diberikan oleh pengelola dan pengunjung di hutan kota ini juga dijumpai pakan seperti biji Sengon (Albizia chinensis), Rambai (Baccaurea motleyana), Ubah Nasi (Eugenia spicata), dan Cempedak Air (Artocarpus kemando). Pada jalur 2 sebagian besar di dominasi oleh semak belukar. Kondisi penutupan lahan tersebut kurang mendukung bagi aktivitas harian monyet ekor panjang seperti istirahat, bermain, berlindung dan tidur.

Monyet ekor panjang yang terdapat di kawasan Hutan Kota Teluk Akar Bergantung memiliki ketergantungan yang besar terhadap pengelola dan pengunjung. Pemberian pakan secara rutin oleh penjaga dan pengunjung menyebabkan beberapa kelompok monyet ini lebih banyak berkumpul di kawasan tertentu, terlebih pada waktuwaktu makan yaitu pada pagi dan sore hari. Beberapa kelompok sengaja mendatangi tempat yang sering didatangi pengunjung untuk menunggu makanan. Makanan yang diberikan pengunjung berupa pisang, ubi, dan jenis buah-buahan lainnya yang tidak ditemukan pada lokasi penelitian.

Kelompok yang menjelajah pada lokasi yang jarang didatangi pengunjung hanya mendapatkan pakan dari alam, namun tumbuhan pakan alami tersebut memiliki musim berbuah sehingga tidak setiap waktu dapat menyediakan pakan bagi monyet ekor panjang di lokasi penelitian. Kelompok ini tidak menetap 
lama di lokasi tersebut, mereka akan kembali pada lokasi yang lebih sering dikunjungi manusia untuk mendapatkan makanan, akibatnya monyet ekor panjang di kawasan hutan kota ini lebih banyak terdapat pada bagian pintu masuk hutan kota. Keadaan ini sama halnya dengan penelitian yang dilakukan oleh Laksana et. al. (2017), dalam penelitian yang dilakukannya di Taman Wisata Alam Pananjung Pangandaran. Kelompok pertama ia temukan berada di Jumlah Individu dan Kelompok Populasi Monyet Ekor Panjang (Macaca fascicularis)

Jumlah individu dan kelompok monyet ekor panjang di seluruh areal penelitian dengan selang kepercayaan sekitar resort BKSDA dan hutan didepan Resort. Kelompok ini termasuk kelompok yang mudah dijumpai di lokasi pengamatan. Kelompok ini selalu mengitari daerah sekitar Resort BKSDA. Pada pagi dan siang hari kelompok ini dapat dijumpai berkumpul di sekitaran Resort untuk mencari makan, baik itu pakan alami di daerah hutan depan resort maupun pakan non-alami yang didapatkan dari pengunjung atau tempat sampah yang tersedia.

95\% masing-masing yaitu jumlah individu terletak antara $-1,38-30,20$ individu/ha dan jumlah kelompok/ha terletak antara $0,72-2,70$ kelompok/ha. Jumlah individu dan kelompok untuk setiap jalur dapat dilihat pada Gambar 2.

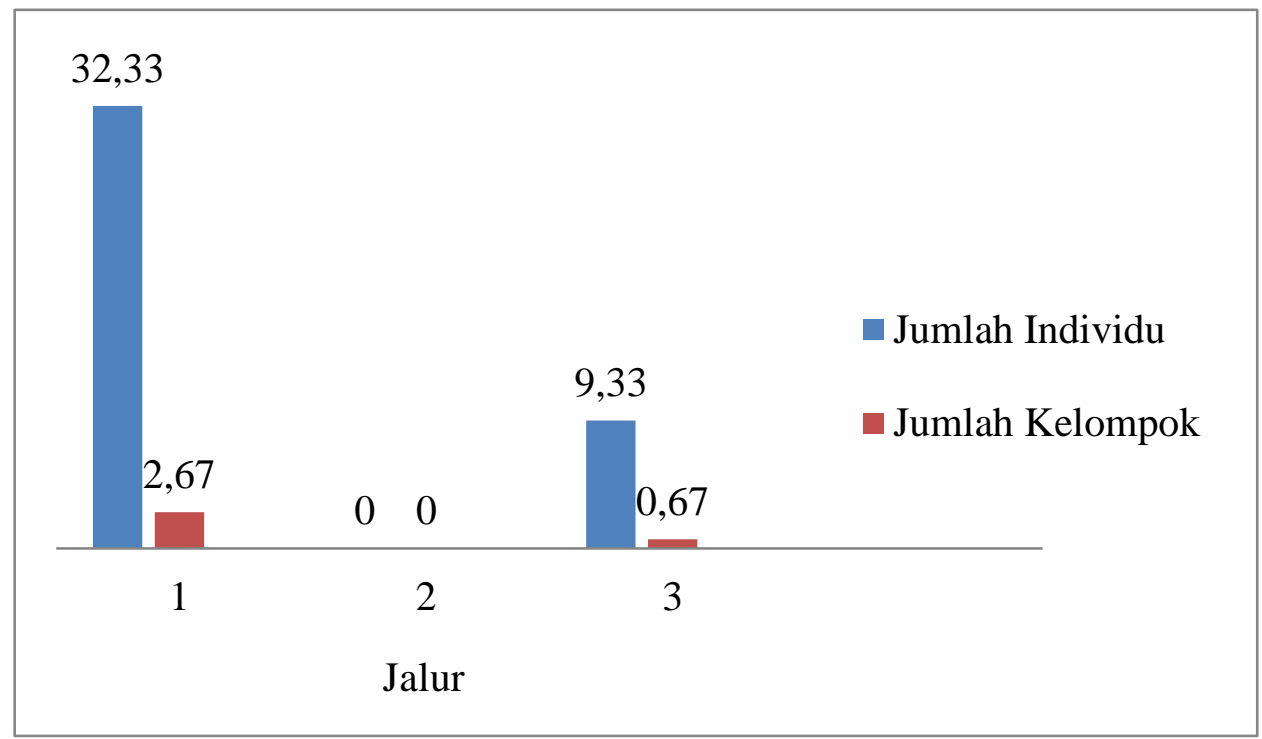

Gambar 2. Jumlah Individu dan kelompok monyet ekor panjang di masing-masing jalur pengamatan (the number of individuals groups of long-tailed macaque on each observation track)

Menurut Supriatna dan Wahyono (2000), jumlah individu setiap kelompok pada masing-masing tipe hutan berbedabeda, misalnya dihutan bakau umumnya berjumlah antara $10-20$ ekor, sedangkan pada hutan primer bisa mencapai 20 - 30 ekor dan pada hutan sekunder yang pernah di teliti, jumlah anggota kelompok mencapai 30 - 50 ekor, bahkan di perkampungan di Sangeh Bali mencapai lebih dari 200 ekor. Pada daerah terganggu seperti 
hutan wisata, jumlah individu dalam kelompok monyet ekor panjang dapat lebih dari 40 ekor karena makanan tersedia dalam jumlah yang melimpah (Crocket dan Wilson, 1978 dalam Sembiring, 2016). Berdasarkan hasil pengamatan, jumlah individu monyet ekor panjang pada kawasan hutan kota Teluk Akar Bergantung yang merupakan hutan wisata, berkisar antara 11-14 ekor. Jumlah ini tergolong rendah untuk tipe hutan terganggu atau hutan wisata.

Jumlah individu maupun kelompok suatu populasi pada suatu kawasan sangat berkaitan erat dengan daya dukung habitatnya. Hal inilah yang menyebabkan terjadinya perbedaan jumlah populasi antara satu kawasan dengan kawasan lainnya. Pengontrolan terhadap penambahan jumlah populasi harus dilakukan. Apabila dilihat dari letak kawasan, lokasi penelitian terletak pada posisi terisolir yaitu berada di antara pemukiman penduduk dan sungai. Kondisi ini dikhawatirkan dapat menyebabkan terjadinya penindihan lahan antara populasi monyet ekor panjang dengan manusia apabila terjadi peningkatan populasi dalam jumlah besar.

Perubahan jumlah populasi monyet ekor panjang pada lokasi penelitian setiap tahunnya belum bisa dipastikan, apakah mengalami penurunan atau penambahan jumlah. Sebelum penelitian ini dilakukan, belum ada data valid terkait jumlah monyet ekor panjang pada kawasan tersebut.

Jumlah Monyet Ekor Panjang (Macaca fascicularis) Berdasarkan Struktur Umur

Berdasarkan hasil pengamatan pada 3 jalur dengan 3 kali ulangan diperoleh jumlah monyet ekor panjang berdasarkan struktur umur seperti pada Gambar 3 berikut.

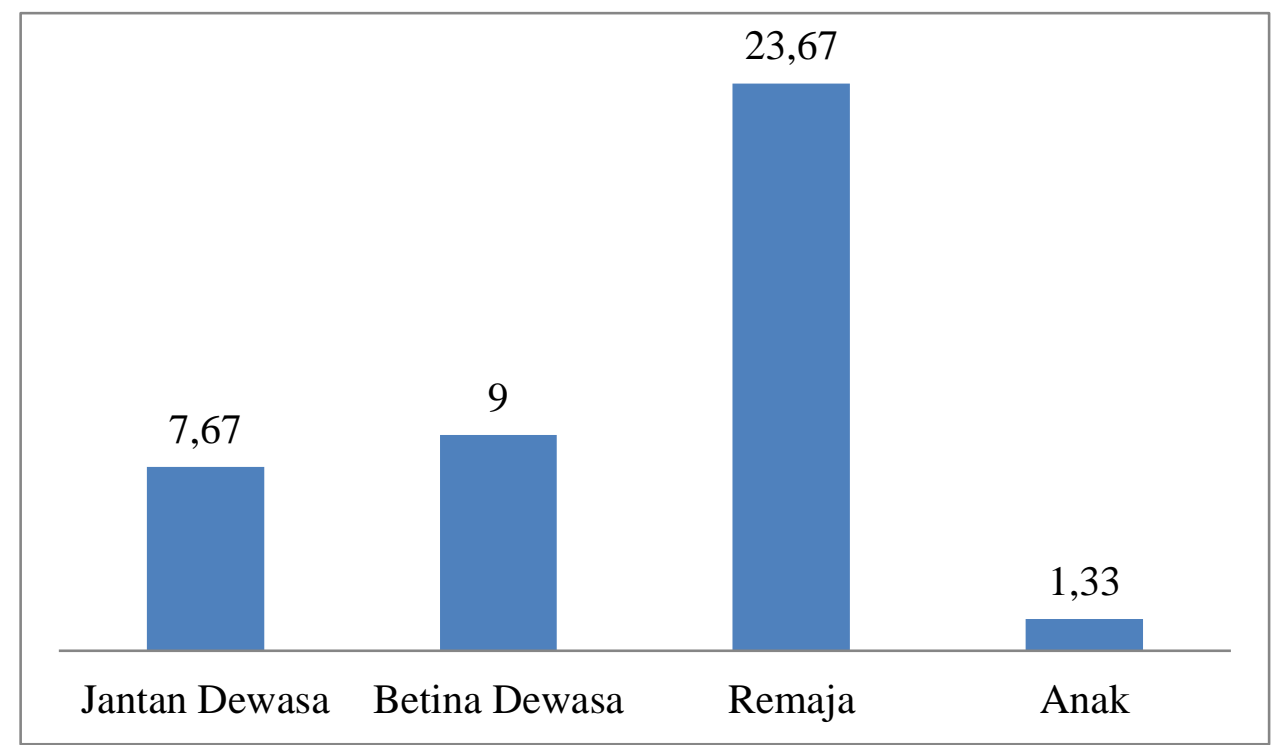

Gambar 3. Jumlah monyet ekor panjang berdasarkan struktur umur (number of long-tailed macaque based on age structure) 
Perbedaan yang mencolok dari setiap kelas umur menunjukkan bahwa adanya ketidakseimbangan dalam perkembangbiakan populasi monyet ekor panjang pada kawasan ini. Menurut
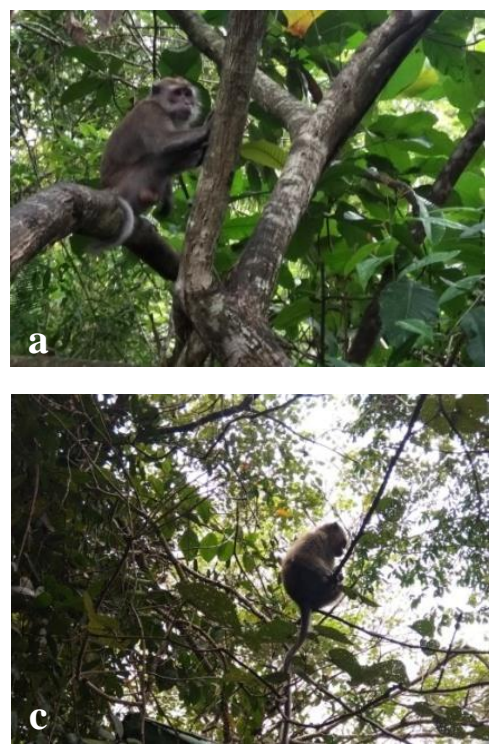

Alikodra (1990) struktur umur dalam suatu populasi dapat menurun apabila jumlah kelahiran (natalitas) lebih kecil dari jumlah kematian (mortalitas).

Gambar 4. (a) monyet ekor panjang jantan dewasa (adult male long-tailed macaque); (b) monyet ekor panjang betina dewasa (adult female long-tailed macaque); (c) monyet ekor panjang remaja (teenage long-tailed macaque); (d) monyet ekor panjang anak dalam gendongan induknya (child long-tailed macaque in his mother's arms)

Jumlah individu dan kelompok monyet ekor panjang di seluruh areal penelitian perlu diketahui sebagai informasi mengenai populasi monyet ekor panjang pada areal penelitian. Hal tersebut sangat penting sebagai tolak ukur apakah perlu dilakukan pelestarian atau pengendalian populasi dalam pengelolaan satwa khususnya monyet ekor panjang di kawasan Hutan Kota Teluk Akar Bergantung.

Pengamatan mulai dilakukan pada pukul 08.00 WIB, dan pada waktu tersebut monyet ekor panjang sudah mulai beraktivitas. Mereka datang dari bagian dalam hutan kota dan mulai mendekat ke arah pintu masuk dan sekitarnya yang masih masuk dalam jalur penelitian (jalur 1) untuk menunggu makanan dari penjaga dan pengunjung yang datang. Pada saat itulah penulis mulai melakukan pengamatan dan perhitungan. Keadaan ini setidaknya mempermudah penulis untuk melakukan penghitungan pada jumlah individu monyet ekor panjang tersebut.

Pada siang hari monyet ekor panjang di jalur 1 mulai masuk ke dalam hutan untuk beraktivitas seperti bermain, istirahat dan aktivitas lainnya di atas pohon, namun tidak sampai ke jalur 2 sehingga selama penelitian dilakukan pada jalur 2 tidak pernah ditemukan kelompok populasi. Kondisi kerapatan 
vegetasi pada jalur 2 yang rendah dan sebagian besar ditumbuhi paku-pakuan dan rumput rambang diduga menjadi fakor penyebab tidak ditemukannya kelompok pada jalur ini. Pada jalur 3, terdapat 1 kelompok yang ditemukan pada ulangan 2 dan ulangan 3. Ulangan 1 tidak ditemukan kelompok pada jalur ini, diduga kelompok tersebut masih berada di luar jalur penelitian. Pada sore

Pada dasarnya, tinggi rendahnya stabilisasi populasi monyet ekor panjang di suatu daerah atau kawasan dapat dipengaruhi oleh beberapa faktor diantaranya (Rizal, 2016):

\section{Kondisi lingkungan}

Hasil pengamatan kondisi lingkungan di lokasi penelitian adalah seperti berikut:

a. Kerapatan vegetasi yang tidak merata pada semua areal Hutan Kota Teluk Akar Bergantung, sehingga terdapat areal yang tidak ditemukan populasi monyet ekor panjang maupun primata jenis lain.

b. Kurangnya sumber pakan alami seperti buah-buahan. Sehingga mengharuskan pemberian pakan langsung dari manusia. Hal ini tentunya akan berdampak terhadap sifat alami monyet ekor panjang dalam interaksinya dengan manusia dan kemampuannya bertahan hidup di alam bebas.

c. Air merupakan elemen yang paling melimpah pada kawasan ini. Posisi hutan yang membentuk Tanjung membuat hutan dikelilingi oleh sungai yang menjadi sumber air bagi satwa yang berada didalamnya.

d. Hutan Kota Teluk Akar Bergantung adalah kawasan yang dikelola oleh Pemkab Ketapang, sehingga adanya penjagaan yang dilakukan. Penjagaan yang dilakukan kurang begitu ketat, sehingga pernah terjadi sekitar empat hari, sekitar pukul 16.00-17.00 WIB monyet ekor panjang kembali mencari makan. Kelompok populasi di jalur 1 yang pada siang hari masuk ke dalam hutan untuk istirahat, bermain dan lainnya, kembali ke area depan untuk aktivitas mencari makan. Setelah itu monyet ekor panjang masuk kembali ke dalam hutan untuk mencari pohon tidur.

kali kasus perburuan ilegal monyet ekor panjang pada kawasan ini, yang berdampak terhadap pengurangan jumlah populasi monyet ekor panjang pada kawasan tersebut.

Pergerakan yang baik dari monyet ekor panjang pada suatu kawasan akan sangat mendukung kestabilan populasi satwa ini. Hal-hal yang harus diperhatikan pada kondisi lingkungan yaitu adanya vegetasi tempat monyet ekor panjang beraktivitas, adanya sumber pakan dan air serta aktivitas manusia (Rizal, 2016).

\section{Jenis Pakan}

Monyet ekor panjang pada kawasan ini sangat menggantungkan pakannya terhadap makanan dengan jenis buahbuahan yang mereka peroleh dari pengelola dan pengunjung yang tidak mereka temukan di kawasan hutan kota. Hal ini menyebabkan satwa ini menjadi terbiasa untuk menunggu makanan dari orang-orang yang datang membawa makanan, sehingga satwa ini selalu mengerumuni pengunjung yang datang dan mereka mengira membawa makanan untuk mereka. Keadaan ini menyebabkan monyet ekor panjang jarang memperoleh makanan secara alami, sehingga monyet ini tidak tersebar merata pada seluruh kawasan hutan kota.

Monyet ekor panjang merupakan satwa pemakan buah (frugivorus), namun jika ketersediaan buah rendah 
atau bahkan tidak tersedia monyet ini dapat memakan jenis pakan lain seperti daun muda, tunas, dan serangga (bersifat opportunistic omnivore) (Bahri et. al., 1996 dalam Sembiring, 2016).

\section{Pergerakan}

Monyet ekor panjang di Hutan Kota Teluk Akar Bergantung memiliki intensitas pergerakan yang kecil dan jarak pergerakan yang pendek. Hal ini terbukti dari 3 kali ulangan ditemukan kelompok monyet ekor panjang dengan rata-rata 2,67 kelompok/jalur yang menumpuk pada satu area (jalur 1) yaitu jalur yang sering didatangi pengunjung. Pada area lainnya dengan jarak yang lebih jauh yaitu jalur 3 hanya ditemukan 0,67 kelompok/jalur monyet ekor panjang. Menurut Rizal (2016), durasi dan jarak pergerakan monyet ekor panjang mengindikasikan sebaran pakan dalam lingkungannya. Durasi yang tinggi dan jarak berpindah yang panjang mengindikasikan menyebarnya sumber pakan. Sebaliknya, durasi yang rendah dan jarak berpindah yang pendek memperlihatkan mengelompoknya sumber pakan.

Pergerakan adalah perilaku berpindah yang terjadi karena adanya kebutuhan satwa akan sumber pakan yang ada pada suatu kawasan, serta substrat sebagai sarana berpindah terkait dengan efisiensi energi yang digunakan. Pernyataan ini menjelaskan adanya hubungan antara perilaku berpindah dengan jenis pohon tertentu (Rizal, 2016). Kebutuhan makan sangat mempengaruhi pergerakan atau perpindahan monyet ekor panjang (Purbatrapsila et. al., 2012).

4. Interaksi dengan Satwa Lain

Pada kawasan Hutan Kota Teluk Akar Bergantug juga ditemukan primata lain seperti Owa (Hylobates muelleri), Bekantan (Nasalis larvatus), dan Lutung
(Trachypithecus sp.). Monyet ekor panjang termasuk jenis primata yang mudah beradaptasi dengan satwa lainnya, karena sering dijumpai terdapat satu individu owa yang selalu bersama dengan kelompok monyet ekor panjang dan interaksi ini tidak menyebabkan terjadinya kompetisi antara kedua jenis primata tersebut.

5. Predator

Baru-baru ini diketahui adanya pelepasan Elang Bondol (Haliastur Indus) dan Elang Putih (Haliaeetus leucogaster) yang selesai di rehabilitasi pada kawasan Hutan Kota Teluk Akar Bergantung. Hal ini berpotensi adanya predator bagi monyet ekor panjang.

Menurut van Schaik \& van Noordwijk (1985) pada suatu ekosistem arboreal, predator yang memburu Macaca fascicularis antara lain elang, anggota Felidae (keluarga kucingkucingan), dan menurut van Schaik \& Mitrasetia (1990) predator yang memburu Macaca fascicularis adalah ular sanca.

\section{KESIMPULAN}

Kepadatan individu monyet ekor panjang di kawasan Hutan Kota Teluk Akar Bergantung pada selang kepercayaan $95 \%$ terletak antara $-0,39$ ind/Ha hingga 8,83 ind/Ha. Kepadatan kelompok monyet ekor panjang di kawasan Hutan Kota Teluk Akar Bergantung pada selang kepercayaan 95\% terletak antara 0,21 kelompok/Ha hingga 0,79 kelompok/Ha. Jumlah individu monyet ekor panjang di Kawasan Hutan Kota Teluk Akar Bergantung Ketapang pada selang kepercayaan $95 \%$ terletak antara $-1,38$ ind/Ha hingga 30,20 ind/Ha. Jumlah kelompok monyet ekor panjang di Kawasan Hutan Kota Teluk Akar Bergantung Ketapang pada selang kepercayaan $95 \%$ terletak antara 0,72 
kelompok/Ha hingga 2,70 kelompok/Ha. Struktur umur monyet ekor panjang di kawasan Hutan Kota Teluk Akar Bergantung Ketapang terdiri dari 7,67 individu jantan dewasa, 9 individu betina dewasa, 23,67 individu remaja dan 1,33 individu anakan.

\section{SARAN}

1. Memperjelas instansi pengelola, guna pelestarian dan pengelolaan hutan kota secara serius.

2. Kurang tersebarnya sumber pakan yang menyebabkan penyebaran monyet ekor panjang menjadi tidak merata, sehingga perlu dilakukan pengayaan sumber pakan di seluruh area hutan kota.

3. Perlu dilakukan patroli dan penjagaan yang ketat minimal sekali setiap pekan pada seluruh area hutan kota.

4. Mengimbau pengunjung untuk tidak memberi makan pada satwa, untuk mengembalikan sifat alami satwa.

\section{UCAPAN TERIMA KASIH}

Pada kesempatan ini penulis ingin menyampaikan ucapan terimakasih kepada semua pihak yang telah banyak membantu dalam penyusunan skripsi ini, yaitu orang tua, dosen pembimbing dan penguji skripsi, dosen pembimbing akademik, staf Dinas Kehutanan Ketapang, petugas hutan kota, Community Development \& Outreaching, dan kawan-kawan atas bantuan secara materil dan immateril serta semangat yang telah diberikan.

\section{DAFTAR PUSTAKA}

Alikodra HS, 1990. Dasar-Dasar Pembinaan Margasatwa. Yayasan Penerbit Fakultas Kehutanan IPB, Bogor.

Gumert MD, Rachmawan D, Iskandar E, Pamungkas J, 2012. Populasi Monyet Ekor Panjang (Macaca fascicularis) di Taman Nasional Tanjung Puting, Kalimantan
Tengah. Jurnal Primatologi Indonesia 9 (1) : 3-12.

Iskandar E, Kyes RC, 2016. Hewan Model Satwa Primata Volum 1 Macaca fascicularis [Tingkah Laku Monyet Ekor Panjang (Macaca fascicularis) di Penangkaran]. Bogor: IPB Press.

Laksana MRP, Rubiati VS, Partasasmita R, 2017. Struktur Populasi Monyet Ekor Panjang (Macaca fascicularis) di Taman Wisata Alam Pananjung Pangandaran, Jawa Barat. PROS SEM NAS MASY BIODIV INDON 3 (2) : 224-229.

Perwitasari D, Farajallah, 2016. Hewan Model Satwa Primata Volum 1 Macaca fascicularis [Distribusi dan Karakteristik Morfologi Monyet Ekor Panjang (Macaca fascicularis)]. Bogor: IPB Press.

Purbatrapsila A, Iskandar E, Pamungkas J, 2012. Pola Aktivitas dan Stratifikasi Vertikal oleh Monyet Ekor Panjang (Macaca fascicularis Raffles, 1821) di Fasilitas Penangkaran Semi Alami Pulau Tinjil, Propinsi Banten. Zoo Indonesia 21 (1): 39-47.

Rizal M, 2016. Populasi Bekantan (Nasalis larvatus, Wurm) di Kawasan Hutan Sungai Kepuluk Desa Pematang Gadung Kabupaten Ketapang Kalimantan Barat. Jurnal Hutan Lestari 4 (4) : 564-569.

Sembiring RP, 2016. Penyebaran dan Kelimpahan Populasi Monyet Ekor Panjang (Macaca fascicularis) di Cagar Alam Sibolangit. Jurnal Sylva Lestari 4 (3) : 47-58. 
Soma IG, Wandia IN, Suatha IK, Widyastuti SK, Rompis ALT, 2009. Dinamika populasi Monyet Ekor Panjang (Macaca fascicularis) di Hutan Wisata Alas Kedaton, Tabanan. Buletin Veteriner Udayana 1 (2) : 47-53.

Subiarsyah MI, Soma IG, Suatha IK, 2014. Struktur Populasi Monyet Ekor Panjang (Macaca fascicularis) di Kawasan Pura Batu Pageh, Ungasan, Badung, Bali. Indonesia Medicus Veterinus 3 (3) : 183-191.

Supriatna J, Wahyono EH, 2000. Panduan Lapangan PRIMATA INDONESIA. Jakarta: Yayasan Obor Indonesia.

Tobing ISL, 2008. Teknik Estimasi Ukuran Populasi Suatu Spesies Primata. VIS VITALIS 1 (1) : 4352.

van Schaik CP, Mitrasetia T, 1990. Changes in The Behavior of Wild Long-Tiled Macaques (Macaca fascicularis) After Encounters with A Model Python. Folia Primatol 55 : 104-108.

van Schaik CP, van Noordwijk, MA, 1985. The Special Role of Male Cebus Monkeys in Predation Avoidance and Its Effects on Group Composition. Primates 2 : 211-221. 